\title{
Una versátil vía de abordaje al esqueleto del tercio medio facial
}

\author{
A versatile route for reaching the mid-third of the facial skeleton
}

\section{Sr. Director:}

De la lectura y estudio del artículo, hemos podido deducir que el plan terapéutico que proponen, en el caso clínico que presentan, parece que consiguen, según la iconografía que exponen, un resultado muy satisfactorio, por lo que debemos felicitarles, desde luego en este caso el procedimiento modificado de la técnica de Casson ha logrado sus objetivos terapéuticos.

El método mantiene sus indicaciones para patologías, no sólo traumatológicas, sino para cirugías oncológicas y/o tumorales del espacio medio facial en sus distintas profundidades, así como para el tratamiento de secuelas del fisurado, etc., como bien indican los autores del artículo que comentamos. No obstante, en lo que a la cirugía oncológica se refiere, con el procedimiento de Casson y sus modificaciones, es preciso seleccionar exquisitamente el caso clínico, para no caer en la tentación, de que por evitar incisiones externas, se pueda perder la perspectiva quirúrgica, que en oncología es obligado que debe ser de la más absoluta radicalidad y si los campos quirúrgicos son muy ajustados como puede ocurrir en este tipo de accesos "cerrados", estamos sometiendo al paciente a una verdadera yatrogenia al dar preferencia a aspectos cosméticos, sabiendo que la cirugía abierta convencional, la que se basa en el diseño de incisiones cutáneas siguiendo trayectos clásicos, avalados por años y años de experiencia, va a permitirnos normalmente accesos más seguros, para acercarnos a la zona de interés quirúrgico.

Siempre es fácil apuntarse, a que cuando aparece una técnica reconocida, el que más y el que menos ya la había hecho antes, en todas o algunas de sus partes y como no pensado en ello, y a veces, esto es verdad. Nosotros mismos, al inicio de la segunda mitad de la década de los setenta, en el Infantil del ahora, Hospital Universitario Miguel Servet de Zaragoza, abordábamos las estructuras nasoseptales mediante un abordaje similar al de Casson, y no lo hacíamos por ingenio, lo hacíamos por absoluta necesidad quirúrgica, ya que no nos sentíamos capacitados técnica ni quirúrgicamente para abordar por vía nasal en niños de poca edad, las estructuras nasoseptales, al ser las narinas de pequeño calibre, que en las secuelas nasolabiales de los fisurados por ejemplo, eran a veces muy dificultosas $y$, por ello, de forma natural buscábamos la vía sublabial, vía que veníamos empleando desde hacía varios años, rutinariamente para la realización de las osteotomías Le Fort I que, al fin y al cabo para nosotros, no deja de ser prácticamente la mitad de la técnica de Casson y diría más, ¿Cuántas veces hemos tenido que soltar el anclaje nasoseptal en cirugías oncológicas del maxilar superior/es cuando el tumor se hacía medial o en cirugías de las secuelas de patologías malformativas y/o traumatológicas?,
From reading and studying this article, it would appear that the proposed therapeutic plan in the case report presented is achieved. According to the iconography revealed, a very satisfactory result is obtained and the authors should be congratulated. In this case, Casson's technique with a modified procedure has achieved the therapeutic objectives.

The method is indicated for not only trauma-type pathologies, but also for oncological and/or tumor midfacial surgery of different depths, as well as for treating cleft palate sequelae etc., as indicated by the authors in the article under discussion. Nevertheless, with regard to oncological surgery, with Casson's procedure and its modification, all clinical cases should be meticulously selected, so as not to fall into the temptation of avoiding external incisions, as the surgical perspective will be lost, which in oncology has to be completely radical. If the surgical fields are very tight, as can occur in these types of "closed" accesses, we will be subjecting the patient to true iatrogenia in order to give preference to cosmetic aspects, in the knowledge that conventional open surgery, based on the designs of skin incisions along classical lines, and supported by many years of experience, will normally permit safer accesses to the surgical area of interest.

When an acknowledged technique appears, someone will always claim to have carried it out before, either in part or completely, and sometimes this is true. We too, at the beginning of the second half of the seventies decade, in the children's hospital that is now the Hospital Universitario Miguel Servet in Zaragoza, reached nasoseptal structures using an approach that was similar to Casson's. We did not do this through ingenuity, but rather as a response to absolute surgical necessity, as we did not feel technically or surgically capacitated to use a nasal approach in very young children to access nasoseptal structures as children's nostrils are very small. Nasolabial sequelae, for example, in cleft patients are sometimes very difficult, and because of this we naturally sought a sublabial approach. This is an approach that for various years we had routinely been using for carrying out Le Fort I osteotomies, which for us at the end of the day is half Casson's technique, and moreover: How may times have we had to release the nasoseptal anchor in oncological surgery involving the upper jaw when the tumor became medial, or in surgery for malformation and/or trauma pathologies? For certain the answer is, numerous times, and we are sure that many surgeons working in the midfacial 
seguro que numerosas veces y estamos convencidos que lo mismo les habrá ocurrido a numerosos cirujanos que actuaran en la región mediofacial por distintas patologías.

No obstante, no tratamos de desmerecer el procedimiento de Casson y las modificaciones que al mismo se han podido venir produciendo a lo largo de los años, es más creo que está bien que existan autores que sean capaces de sintetizar procedimientos casi habituales, dándoles una sistemática en su diseño y en sus posibles indicaciones, esto se debe agradecer al autor referido. Hoy día desde que dio a conocer en Plasti Reconstr Surg 1974; 53: 1023 , The midface deglobing procedure de Casson PR, Bonanno PC, Converse JM, siguen saliendo más y más modificaciones no sólo en el aspecto técnico quirúrgico sino también en el de sus aplicaciones terapéuticas, para no extendernos en el Year Book de 1987 otorrinolaringología cirugía de cabeza y cuello aparece referenciada la publicación de 1972 Gerald B. Healy de la Universidad de Harvard, "An Approach to the Nasal Septum in Children" Laryngoscope 1986;96:1239-42, y más recientemente, en Neurosurgery 2002; 50:4, aparece Deglovin Transfacial Approach with Le Fort I and Nasomaxillary Osteotomies: Alternative Transfacial Approach de entre otros Kaguhiko Kyoshima, y colaboradores pertenecientes a los departamentos de Neurocirugía y Plástica de Shinshu University School of Medicine, Matsumoto, Japón para acceder a la región central de la base del cráneo y ya por último acabamos de ver en "The British Association of Plastic Surgeons" 2004; 57:156-9 de R. Bracaglia, etc., su trabajo "Double Lateral Osteotomy in Aesthetic Rhinoplasty" que consigue por vía endonasal resultados similares al caso que se presenta en el artículo que comentamos con 210 casos tratados, en definitiva pues siempre hemos pensado que técnicas razonables en buenas manos pueden ser excepcionales aunque sin duda las técnicas sobresalientes en manos no excepcionales son las que mejores resultados dan, al facilitar la actividad quirúrgica.

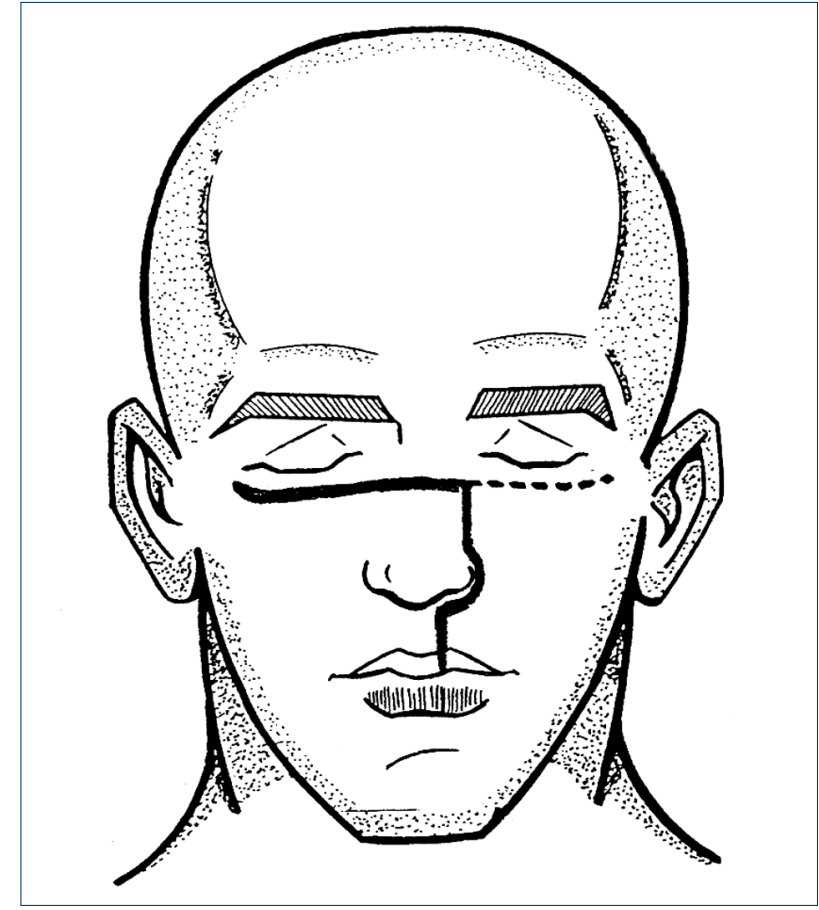

Figura 1. Incisiones cutáneas. La insición subpalpebral izquierda puede extenderse por la línea de puntos.

Figure 1. Cutaneous incisions. The left incision under the eye lid can be extended along the dotted line.

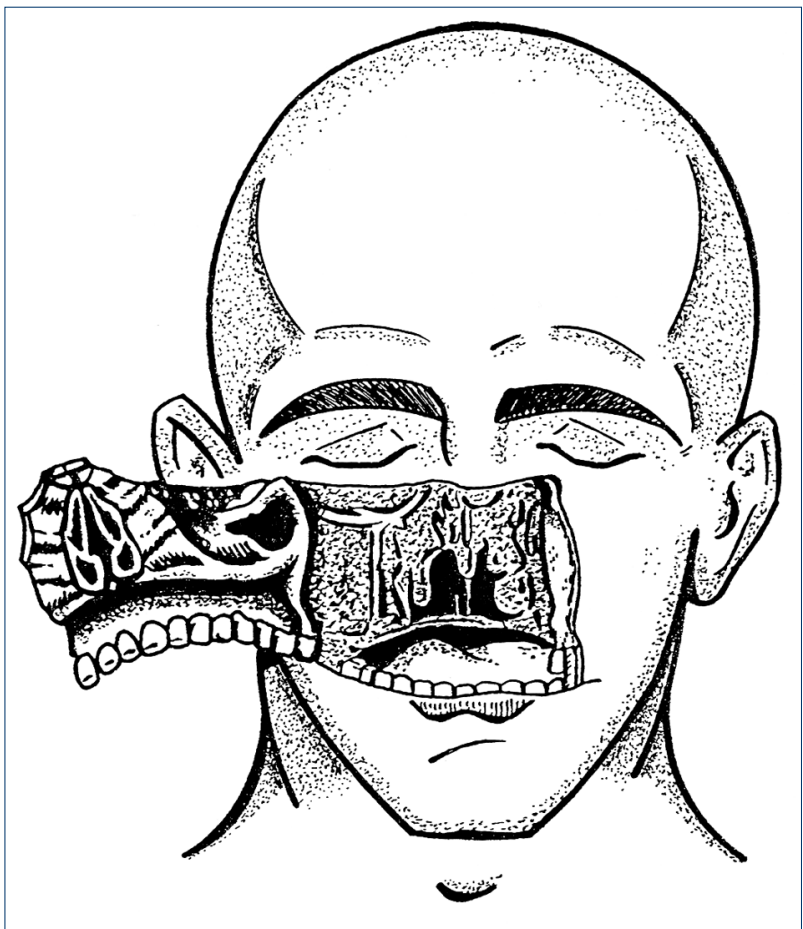

Figura 2. Apecto del campo operatorio después de realizar la movilización del maxilar y de las estructuras nasales.

Figure 2. Appearance of the operating field after the maxilla and nasal structures have been moved. area, because of different pathologies, have also experience this.

Nevertheless, we are not trying to belittle Casson's procedure and its modifications over the years. Moreover, I believe that it is good to have authors that are able to synthesize procedures that are practically habitual, cataloging their design and their possible indications, and the authors should be thanked for this. Ever since the appearance in Plastic Reconstructive Surgery. 1974 Jan; 53(1): 102-3, of The midfacial degloving procedure by Casson PR, Bonanno PC, Converse JM, more and more modifications are appearing, not only of the surgical technique, but also of its therapeutic applications, without going into the 1987 Year Book of Otorhinolaryngology, surgery of the head and neck which refers to the 1972 issue of Gerald B. Healy from Harvard University and, "An Approach to the Nasal Septum in Children" Laryngoscope 96:1239-1242, November 1986 and more recently in Neurosurgery Vol. 50, No.4, April 2002, the Degloving Transfacial Approach with Le Fort I and Nasomaxillary Osteotomies: Alternative Transfacial Approach including Kaguhiko Kyoshima, M.D. and the relevant collaborators of the departments of Neurosurgery and Plastic surgery of the Shinshu University School of Medicine, Matsumoto, Japan for reaching the central region of the skull base, and lastly in The British Association of Plastic Surgeons (2004) 57,156-159 R. Bracaglia's work has just appeared "Double Lateral Osteotomy in Aesthetic Rhinoplasty" that, using an endonasal 
Algo de esto puede ocurrir con las técnicas transfaciales a cielo abierto, en ellas los campos quirúrgicos obtenidos facilitan la actividad quirúrgica sin grandes impedimentos y además con la circunstancia de que el diseño de las incisiones cutáneas que discurren por trayectos anatómicos muy meditados y de larga tradición quirúrgica, como ocurre por ejemplo con la clásica incisión de Weber-Fergusson, las cicatrices postquirúrgicas resultan prácticamente invisibles, eso sí, siempre que los volúmenes a movilizar estén diseñados en verdaderos bloques anatómicos sin particiones que luego muchas veces dan lugar a la formación de secuestros con las consiguientes fístulas cutáneas que van a dejar huellas imperecedederas.

Es probable que la aparición de las técnicas transfaciales abiertas, aprovechando incisiones tipo Weber Fergusson, que son la base de los colgajos mucoosteomusculocutaneos que dan cuerpo a la cirugía transfacial y sus modificaciones, haya servido precisamente para actualizar y sacar más a la luz las técnicas cerradas, porque y no es malo, que los cirujanos acudan a aquellos procedimientos que consideren menos agresivos, pero, eso sí, sin perder las perspectivas terapéuticas, en beneficio de las cosméticas, como antes señalábamos. Nosotros mismos ya describimos cómo el acceso tipo Le Fort I se podía emplear cómo vía de abordaje transfacial a las regiones fundamentalmente retromaxilares y para otras indicaciones: "Osteotomy of Le Fort I to reach the rhinopharynx (complementary note a-Desarticulación temporal pediculada a mejilla del maxilar superior (es) como vía de abordaje transfacial a las regiones fundamentalmente retromaxilares y para otras indicaciones (Vía maxilopterigoidea). Rev Iberoamer Cirug Oral Maxilof 1983:5:81.

Quizás, nos atreveríamos a sugerir a los autores del artículo que estamos comentando, que valorasen para casos seleccionados la posibilidad de emplear la intubación submental, o quizá el despegamiento y la movilización de las partes blandas mediofaciales. Notarían que sería más fácil y se evitaría que el tubo orotraqueal actuara como anclaje de las mis-

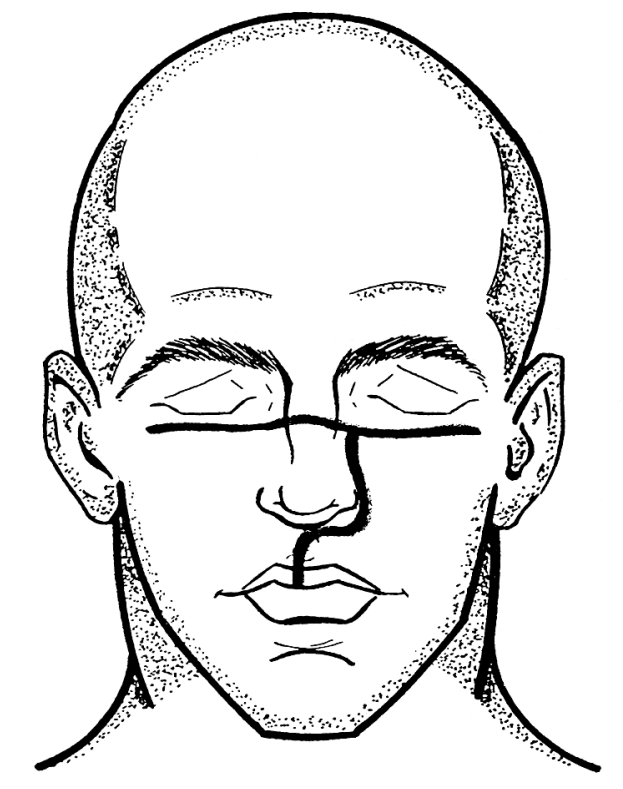

Figura 3. Incisiones cutáneas. Figure 3. Cutaneous incisions.

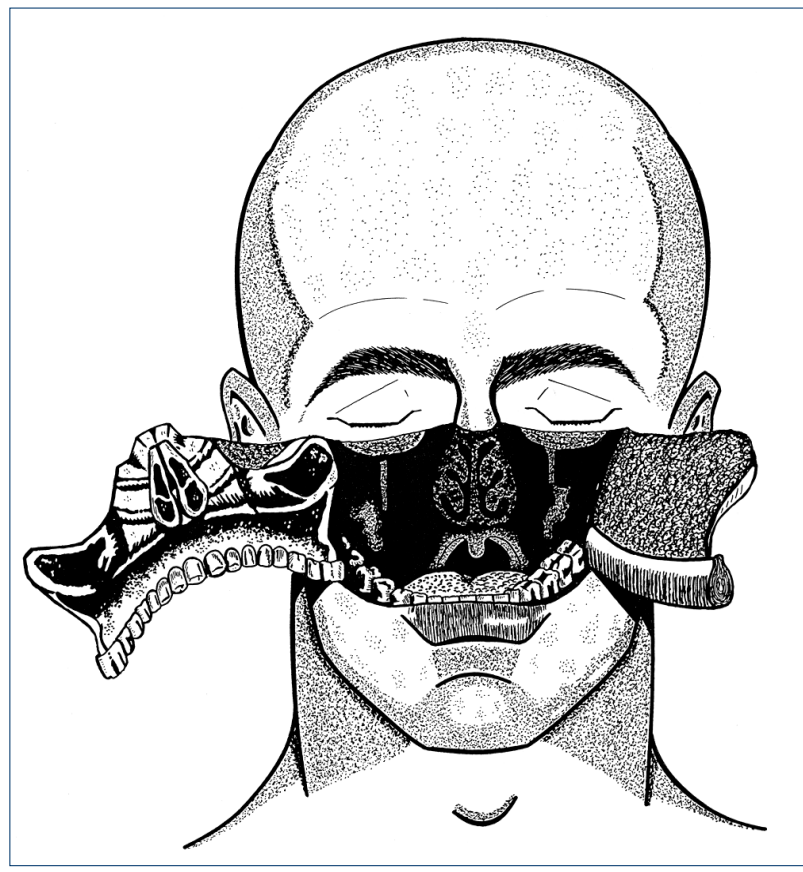

Figura 4. Apecto final. Los contenidos de ambos maxilares y las estructuras nasales y etmoidales están incluidos en los colgajos laterales, concretamente en la figura en el lado derecho.

Figure 4. Final appearance. The contents of the jaw together with the nasal and ethmoid structures are included in the lateral flaps, in the figure on the right to be exact. approach, achieves similar results to those in the article discussed with 210 treated cases. In short, we have always felt that reasonable techniques in good hands can be exceptional, although excellent techniques in not so exceptional hands undoubtedly give the best results, as surgical activity is facilitated. This can occur to a certain extent with transfacial open sky techniques. Here the surgical fields obtained facilitate surgical activity, and there are no great impediments. Given that the design of the cutaneous incisions running along anatomic lines have been carefully thought out, and that they have a long surgical tradition, such as for example the classical Weber Fergusson incision, postsurgical incisions are practically invisible; that is providing the volume to be moved has been designed as true anatomic blocks, without partitions, as these on many occasions will lead to the formation of sequesters and the resulting skin fistulas will leave permanent traces. It is probable that the appearance of open transfacial techniques that make the most of Weber Fergussontype incisions, which are the base of mucoosteomuculocutaneous flaps that give body to transfacial surgery and its modifications, has served precisely to bring closed techniques up to date and more into the light, because it is not a bad thing for surgeons to be inclined towards the procedures that they find less aggressive, providing the therapeutic perspectives are not lost for the benefit of cosmetic perspectives, as mentioned previously. We ourselves described how the Le Fort I type approach could 
mas, eso sí claro, hay que hacer una incisión submental, por ahora.

Felicitar pues a los autores, por haber afinado el acceso mediofacial por técnicas cerradas. Sin contradecir, para nada, con dichas técnicas, nosotros hemos diseñado nuestras osteotomías transfaciales y sus modificaciones, en su mayoría, a través de incisiones externas y, en nuestras manos, los resultados estéticos y funcionales han sido excelentes. Queremos agradecer que la Dirección de la Revista nos haya animado a publicar junto con el artículo comentado, los esquemas de nuestra metodología transfacial, para llegar a la cirugía craneofacial pediculada en sus distintos diseños y a la que se puede asociar el empleo de nuestro arco de tracción craneofacial, como ayuda en la cirugía de acceso a la base del cráneo, en técnicas de distracción, traumatológicas y en procesos rehabilitadores como pueden ser, en el tratamiento de la anquilosis temporomahdibular, uni o bilateral, etc. Debe entenderse que la cirugía abierta que preconizamos tiene que ser elegida libremente para cada caso clínico a tratar, nadie debe de tratar de imponer si hacer técnicas cerradas o abiertas. Hoy sólo cabe, el criterio clínico serio y sereno. Es un hecho curioso, al menos para nosotros, que si se repasa la literatura médica en el tema referente a los diferentes accesos que comentamos, cómo siendo más antiguas las descripciones cerradas, desde que se dieron a conocer las técnicas transfaciales abiertas, aquellas se han hecho más habituales, es el ejemplo del péndulo, si alguien con cierto éxito desarrolla un procedimiento siempre surgen autores, que parece que llevan la contraria. Pues ni lo uno, ni lo otro, es el criterio desinteresado, el que debe prevalecer sobre el enfermo a tratar. A veces hemos dicho, no obstante, que casi todas las técnicas en buenas manos, suelen ser excelentes, ya podemos describir una técnica más o menos maravillosa, que si, no se realiza con los parámetros adecuados, puede llevar a su fracaso y empiezan a atribuirle resultados muchas veces insospechados, que sorprenden a los autores de las mismas. Algunos de los esquemas que presentamos, sobre todo en la cirugía craneofacial pediculada, no los hemos llevado a efecto todavía, porque no se nos ha presentado el caso, pero por si sucediera, la metodología, ahí está.

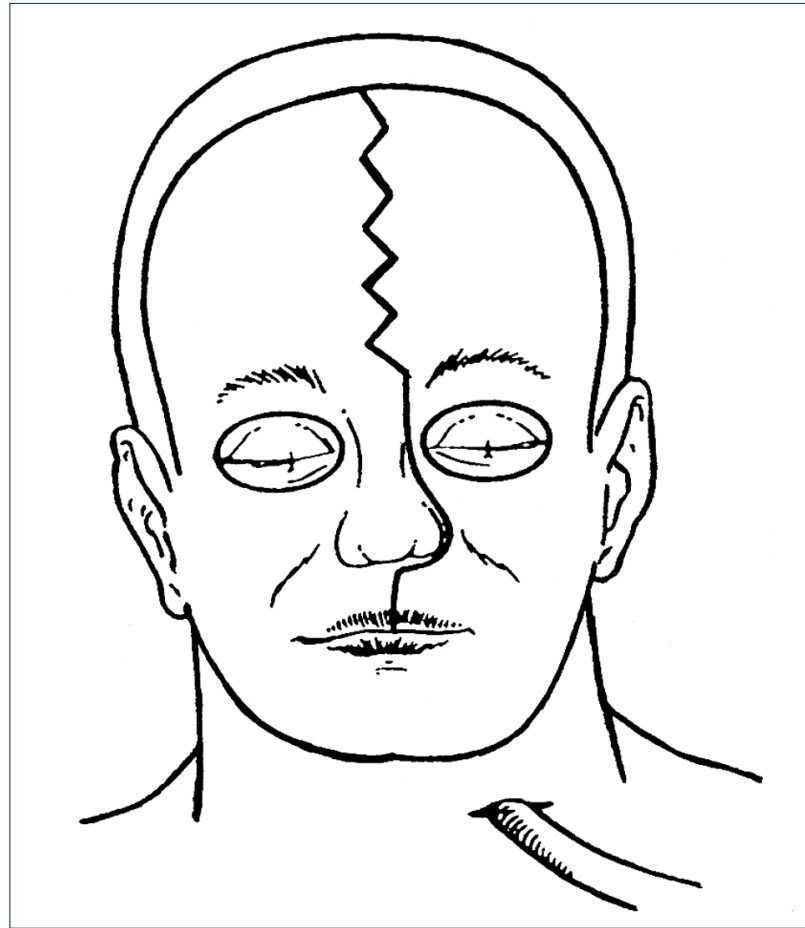

Figura 5. Líneas de incisión cutáneas.

Figure 5. Cutaneous incision lines.

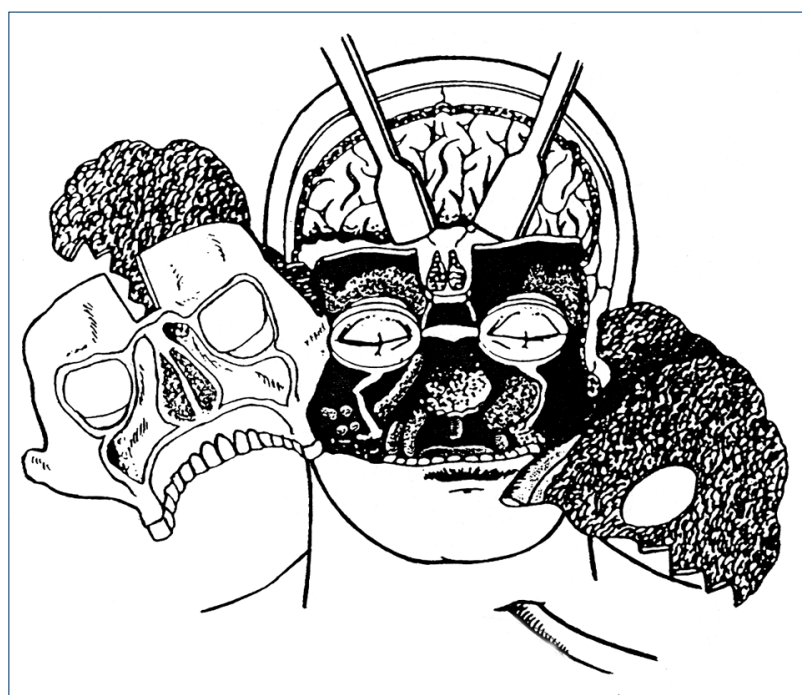

Figura 6. La región craneofacial completa y el bloque alveolomaxilar-dental es desplazado.

Figure 6. The complete craniofacial region and the alveolar-maxillaryFigure 6. The complete be used as a transfacial approach in areas that are basically retromaxillary and for other indications: "Osteotomy of Le Fort I to reach the rhinopharynx (complementary note forDesarticulación temporal pediculada a mejilla del maxilar superior (es) como vía de abordaje transfacial a las regiones fundamentalmente retromaxilares y para otras indicaciones (Vía maxilopterigoidea). Rev. Iberoamer. cirug. Oral y Maxilof. 5 (1983) 81.

Perhaps we might suggest to the authors of the article under review that the possibility of using submental intubation should be evaluated in selected cases, or perhaps degloving and mobilization of the midfacial soft tissue. This would avoid the orotracheal tube acting as an anchor and facilitate things, although a submental incision would of course have to be made.

We would like to congratulate the authors for refining the midfacial approach using closed techniques. Without wishing to make any contradiction, we have used these techniques to design our own transfacial osteotomies with modifications, mostly using external incisions and, in our hands, the aesthetic and functional results have been excellent. We would like to thank the Directors of the Journal for encouraging us to publish, together with the article discussed, diagrams of our transfacial methodology for pedicled transfacial surgery in its different designs and which can be used in conjunction with our craniofacial traction arch. This aids the surgical access to the base of the skull in distraction techniques, trauma and in rehabilitation processes which can be for uni- or bilateral temporomandibular ankylosis treatment, etc. 
Es tema de actualidad los trasplantes de cara, quizá no se tarde mucho, en que sean una realidad y al respecto quisiéramos llamar, una vez mas la atención de nuestros diseños transfaciales y los que se obtienen con los de la cirugía cráneo-facial pediculada, preparados para si fuera el caso, trasplantar esas unidades tridimensionales funcionales, en bloque, ya que pensar exclusivamente, en trasiegos de partes blandas aunque solo falten éstas, puede ser un error de concepto y si así se hiciera, difícilmente caben esperar resultados favorables. Un trasplante de cara hoy día debe interpretarse, cuando existe la necesidad de aportar grandes volúmenes, ya que para resolver pérdidas más o menos moderadas las técnicas reconstructivas convencionales, son las indicadas.

\section{Francisco Hernández Altemir} Profesor Asociado

Jefe de Servicio de Cirugía Oral y Maxilofacial del Hospital Universitario Miguel Servet. Zaragoza, España Facultad de Medicina

\section{Sofía Hernández Montero, Médica Especialista en Cirugía Oral y Maxilofacial \\ Susana Hernández Montero Médico Odontólogo \\ Elena Hernández Montero Médico Especialista en Otorrinolaringología}

Manuel Moros Peña Médico Especialista en Pediatría y Puericultura

\section{Bibliografía}

1. Álvarez Vicent JJ, Romero Castellano L, Domingo Carrasco C. Maxilotomía en bisagra o desarticulación temporal pediculada a mejilla del maxilar superior. Poch Broto J, Trasera J, García Ibáñez E, Claros P, Vellaneda RA. Ponencia Oficial del XV Congreso Nacional Cirugía de la Base del Cráneo: Cadiz 19-23 de septiembre de 1993;189-96.

2. Federico Biglioli MD, Pietro Mortini MD, Mario Goisis MD, Alessandro Bardazzi MD. Submental Orotracheal Intubation: An Altemative to Tracheotomy in Transfacial Cranial Base Surgery. Skulll Base 2003;189-96.

3. Bracagliaa R, Fortunato, Gentileschia. Double lateral osteotomy in aesthetic rhinoplasty. Br Ass Plast Surg 2004;57:156-9.

4. Brown AM, Lavery KM, Millar BG. The transfacial approach to the postnasal space and retromaxillary structures. Br J Oral Maxillofac Surg 1991;29:424.

5. Casson PR, Bonanno PC, Converse JM. The midface degloving procedure. Plast Reconstr Surg 1974;53:102-3.

6. Children's Hospital, Boston, Mayo 1997: Skull base surgery treats hard-to-reach tumors.

7. Dromer RB. The history of the Le Fort I osteotomy. J Maxillofac Surg 1986;14:119.

8. E W H To, Frcs, Ehy Yuen, Frcr, W M Tsang, Fracds, Ech Lai. Mbchb, G K C Wong, Afrcs, D T M Chan, Chan, Frcs, J M K Lam, Frcs, A Ahuja, Frcr, and S Poon, Frcs. The use of stereotactic navigation guidance in minimally Invasive transnasal nasopharyngectomy: a comparison with the conventional open transfacial approach. Br J Radio/2002;75:345-50.
It should be understood that the open surgery that we support should be freely chosen depending on each clinical case to be treated. No one should impose either closed or open techniques. These days there is only room for serious and serene clinical criteria. It is, at least for us, a curious fact that if the medical literature is reviewed with regard to the different accesses discussed, and despite closed descriptions being older, ever since the appearance of open transfacial techniques, the former have become more habitual. This is an example of the pendulum effect; if someone develops a procedure with a certain degree of success, you will always find authors emerging who disagree. It should be neither one thing nor the other. Impartial criteria should prevail with regard to the patient requiring treatment. We have nevertheless sometimes said that nearly all techniques in good hands tend to be excellent. However, a more or less magnificent technique, if not carried out with the right parameters, could lead to failure and unexpected results could be attributed to the technique much to the surprise of its authors. We have not been able to put into practice some of the diagrams presented, particularly in pedicled craniofacial surgery because the case has not arisen, but should this happen the methodology is there.

Face transplants are currently a popular subject, and perhaps in the not too distant future they may be a reality. In this sense we would, once again, like to draw attention to our transfacial designs and those regarding pedicled craniofacial surgery. These are in preparation, should the case arise, for the transplantation of these functional tridimensional units, as a block, because contemplating only the transferal of soft tissue even though only this may be required, may be a conceptual error. And if this were to occur, it would be difficult to expect favorable results. A face transplant these days should be carried out when there is a need for large volumes, because for resolving more or less moderate losses, conventional reconstructive techniques are the most indicated. 
9. Gibbons SD, Wiesenfed D, Millar H, Busmanis IA. Removal of a Retromaxillary Schwannoma Via a Temporal Approach. J Oral Maxillofac Surgery 1991; 49:191-3.

10. Hemández Altemir F. Desarticulación temporal pediculada a mejilla del maxilar superior(es) como vía de abordaje transfacial a las regiones fundamentalmente retromaxilares y para otras indicaciones (Vía maxilopterigoidea). Una nueva técnica. Estoma 1982;3:75.

11. Hemández Altemir F. Desarticulación temporal pediculada a mejilla del maxilar superior(es) como vía de abordaje transfacial a las regiones fundamentalmente retromaxilares y para otras indicaciones (Vía maxilopterigoidea)." Una nueva técnica. Rev Iberomer Cirug Oral y Maxillofac 1983;81.

12. Hemández Altemir F. A new technique of endotracheal intubation (submental way). Rev Iberoamer Cirg Oral y Maxillofac 1984;61:165.

13. Hemández Altemir F. Transfacial Acces to the Retromaxillary Area. J Max Fac Surg 1986;14.

14. Hernández Altemir F. Transfacial access to the retromaxillary area and some technical modifications. European Association for Maxillo-Facial Surgery 8 th Congress Monday 15th to Friday 19th. September 1986.

15. Hernández Altemir F. Symposium. Dismantling and Reassembly of the Facial Skeleton, Libero Instituto Universitario, Carlo Cattaneo. Aula Magna -Castellanza (Varese). Nov. 26, 1994.

16. Altemir Approach for Midfacial Acces. Advanced operative techniques in Head and neck surgery Regional Centre for Maxillofacial Surgery, University Hospital Aintree. Liverpool Edited by ED Vaughan 2001.

17. Ivo $P$, Chandra N, Laligam N, Moises Arriaga MD. Facial translocation: A new approach to the cranial base. Otolaryngol Head Neck Surg 1990;103:413-9.
18. Janecka IP, Nuss DW, Sen CN. Midfacial split for access to the cranial base. Acta Neurochirur 1991;53(suppl:199-203).

19. Ivo P Janecka, MD Pittsburgh, 1 etter to Catalano PJ, Biller HF. Extended osteoplastic maxillotomy: a versatil new procedure for wide acces to the central skull base and infratemporal fossa. Arch Otolaryngol Head Neck Surg 1993;119:394-400.

20. Ivo P, Laligam N, Sal Ramasastry MD, Hugh D, Leop Barnes E, Frank Dámico Ph. Cranial Base Surgery: Results in 183 patients. Otolaryngology-Head Neck Surg 1994;110:539-46.

21. Ivo P. Classification of facial translocation approach to the skull base. Otolaryngol Head Neck Surg 1995;112:579-85.

22. Kyoshima K, Matsuo K, Kushima H, Oikawa S, Idomari K, Kobayashi S. Degloving Transfacial Approach with Le Fort I and Nasomaxillary Osteotomies: Alternative Transfacial Approach. Neurosurg 2002; 50:813.

23. Moloney F, Worthington P. The origen of the Le Fort I maxillary osteotomy: Cheever's operation. J Oral Surgery 1981;39.

24. Paparel Bailey. Transfacial acces to the retromaxillary area. 1987 Book of the Year. Otolaryngol Head Neck Surg.

25. Yoav P. Talmi, Horowitz Z, Yahalom R, Bedrin L. Coronoidectomy in maxillary swing for reduce the rencidence and seventy of trismus -a reminder. J Cranio-Maxillofacx Surg 2004;32:19-20.

26. The New York Times: April 15, 1997 Science Times. Doctors and Patients Brave Surgical No Man's Land.

27. Tresserra L, Collares MV, Regas JS, García Vaquero JA. Maxillectomy in Childhood. J Cranio-Max-Fac Surg 1991;19:155-60.

28. Wei WI, Lam KH, Sham JST. New approach to the nasopharyns: the maxillary swing approach. Head Neck 1991;13:200-7. 